Section Editor

John J. Millichap, MD

Mystery Case:

\title{
Acute clot within P1 segment mimicking cisternal hemorrhage in Percheron infarction
}

Frédéric London, MD Andre Philippe Peeters, MD

Thierry Duprez, MD

Correspondence to

Dr. Peeters:

andre.peeters@uclouvain.be
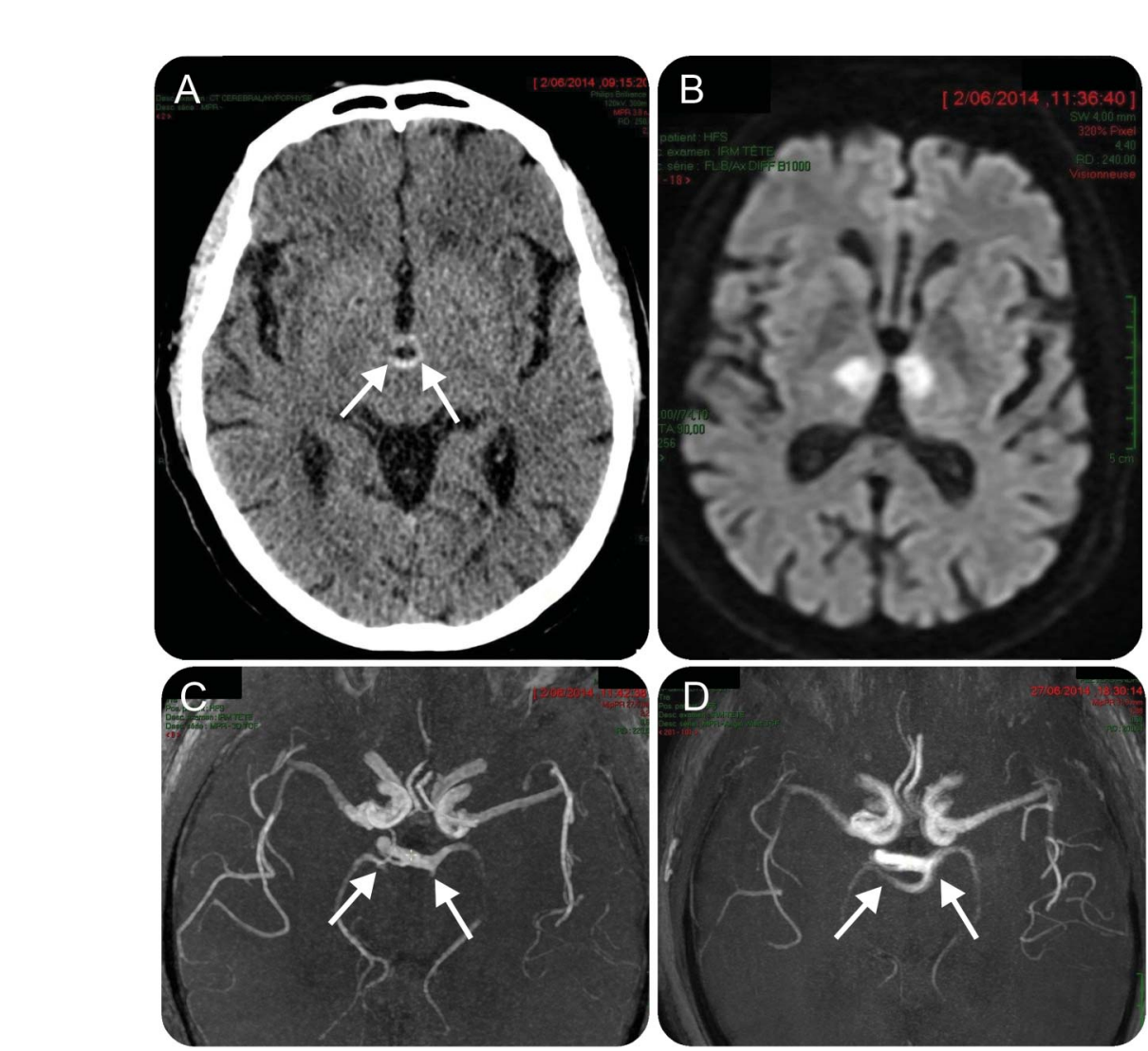

(A) Admission CT shows abnormal hyperdensity within interpeduncular cistern (arrows). (B) Admission MRI (diffusionweighted imaging) shows mirrored acute infarction within both thalami. (C) Magnetic resonance angiography (MRA) shows right P1 occlusion (between arrows). (D) Follow-up MRA 25 days later shows complete recanalization of right P1 (between arrows).

A 72-year-old man was admitted after sudden onset of coma (Glasgow Coma Scale score 6/15). At clinical examination he had tetraparesis, bilateral Babinski signs, bilateral unresponsive miosis, and vertical gaze palsy. Head CT scan demonstrated a linear hyperdensity outlining the interpeduncular cistern (figure, A). Additional MRI examination was performed promptly to rule out blood extravasation since thrombolysis was considered. Bilateral Percheron artery type II infarction was demonstrated on diffusionweighted imaging (figure, B). Magnetic resonance
(MR) angiogram demonstrated complete occlusion of right $\mathrm{P} 1$ segment (figure, $\mathrm{C}$ ), the abnormal hyperintensity seen on CT image corresponding to the occluding fresh clot. Comparison of CT and MRI data appeared mandatory to reach an appropriate therapeutic option in this peculiar condition. Follow-up MR angiogram demonstrated complete recanalization (figure, D).

The patient received IV thrombolysis with recombinant tissue plasminogen activator at 6 hours and 15 minutes after stroke onset, with incomplete recovery (modified Rankin Scale 4 at 3 months).

From the Department of Neurology (F.L., A.P.P.) and the Neuroradiology Section of the Radiology Department (T.D.), Cliniques Universitaires UCL St-Luc, Brussels, Belgium.

Go to Neurology.org for full disclosures. Funding information and disclosures deemed relevant by the authors, if any, are provided at the end of the article. 


\section{AUTHOR CONTRIBUTIONS}

Frédéric London: drafting/revising the manuscript, study concept or design, analysis or interpretation of data, accepts responsibility for conduct of research and final approval. Andre Philippe Peeters: drafting/revising the manuscript, accepts responsibility for conduct of research and final approval. Thierry Duprez: drafting/revising the manuscript, accepts responsibility for conduct of research and final approval, acquisition of data.

\section{STUDY FUNDING}

No targeted funding reported.

\section{DISCLOSURE}

The authors report no disclosures relevant to the manuscript. Go to Neurology.org for full disclosures.

\section{MYSTERY CASE RESPONSES}

The Mystery Case series was initiated by the Neurology ${ }^{\circledR}$ Resident \& Fellow Section to develop the clinical reasoning skills of trainees. Residency programs, medical student preceptors, and individuals were invited to use this Mystery Case as an educational tool. Responses were solicited through a group e-mail sent to the American Academy of Neurology Consortium of Neurology Residents and Fellows and through social media.
All respondents correctly identified the area of infarct seen on MRI and nearly all answers regarding etiology were also correct. Depicted in this Mystery Case are bilateral thalamic infarcts as a result of an occlusion of the artery of Percheron. The first image depicts a hyperdensity in the interpeduncular cistern as a result of an acute right P1 occlusion.

The artery of Percheron, named for Gérard Percheron, who first described it, is an anatomic variant in which a single branch off one of the posterior cerebral arteries supplies the bilateral paramedian thalami. Usually this area and the rostral midbrain are supplied by perforating vessels originating from the posterior cerebral arteries bilaterally. Occlusion of the artery of Percheron results in bilateral thalamic infarcts and can also involve the midbrain. Clinically, one of the hallmarks of this pattern of infarct is marked somnolence.

\section{Ilena George}

Yale University School of Medicine, New Haven, CT 


\section{Neurology}

\section{Mystery Case: Acute clot within P1 segment mimicking cisternal hemorrhage in Percheron infarction}

Frédéric London, Andre Philippe Peeters and Thierry Duprez

Neurology 2016;87; e204-e205

DOI 10.1212/WNL.0000000000003245

This information is current as of October 24, 2016

\section{Updated Information \& Services}

Subspecialty Collections

\section{Permissions \& Licensing}

\section{Reprints}

including high resolution figures, can be found at: http://n.neurology.org/content/87/17/e204.full

This article, along with others on similar topics, appears in the following collection(s):

\section{All Cerebrovascular disease/Stroke}

http://n.neurology.org/cgi/collection/all_cerebrovascular_disease_strok e

CT

http://n.neurology.org/cgi/collection/ct

\section{DWI}

http://n.neurology.org/cgi/collection/dwi

\section{Infarction}

http://n.neurology.org/cgi/collection/infarction

MRI

http://n.neurology.org/cgi/collection/mri

Information about reproducing this article in parts (figures,tables) or in its entirety can be found online at:

http://www.neurology.org/about/about_the_journal\#permissions

Information about ordering reprints can be found online: http://n.neurology.org/subscribers/advertise

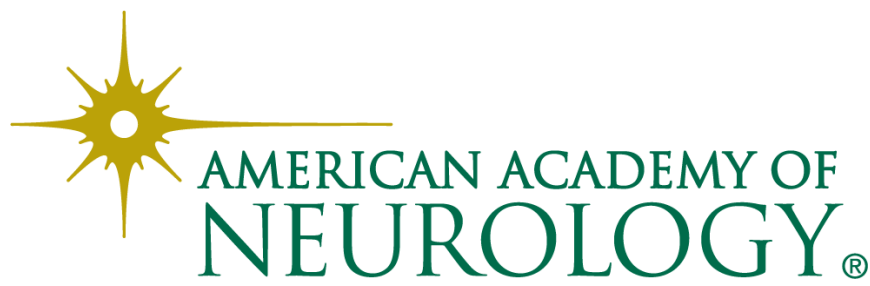

